\title{
Handy Tech-Medicine
}

\author{
Priyadharshini. SP, R. Velvizhi, Sadagopan S
}

\begin{abstract}
The high price of medicines is a major concern in India. High prices make medicines unaffordable and threaten to the people. Beside this price confusion there also a confusion will exists in which treatment system to choose. In India, there are many treatment systems which majorly includes Allopathy, Ayurveda and Homeopathy. The proposal of our project will provide knowledge to the people in all medical firms including the treatments and medicines. Our solution is presented in the form of android app. It includes three categories Allopathy, Homeopathy and Ayurveda. It is used to compare the costs of medicines of various brands. It can help out to filter the cheapest branded medicine. It allows online purchase of medicine, pill remainder, emergency tips, health tips, articles, offers and online consultation with doctors. It also involves GPS tracking system to find the nearby hospitals and medical shops. The major advantage of our app is it can provide the comparison solution in all medical firms. So the details like cost difference, treatment difference, side effects, chemical composition, natural medicines, food methods all come into one application.
\end{abstract}

Keywords : GPS Tracking System, Allopathy, Ayurveda

\section{INTRODUCTION}

In the present world, hospitals and clinics have many advanced treatments and medical facilities. But most of the times poor people cannot afford to that structure. They found difficulties to buy all the medicines prescribed by the doctor. Some people will believe in traditional or natural medical treatment so they will switch over to Ayurveda or Homeopathy[1],[3],[5]. The GENERIC MEDICINE concept is evolving to provide low cost medicine which can be afforded by all the people. Even though, generic version is not available for medicines like Atacand, Cozaar, Diova, Micardis and other angiotensin-receptor blockers(ARB) many brands produce the drugs in different names and different costs. For the same problem ARB, medicines like diuretics, beta blockers available in Homeopathy and natural methods like pranayama, abhyanga for this hypertension available in Ayurveda. For this challenging environment in India we provide to prefer low cost medicines and treatments in different systems[2],[4],[6].

\section{OBJECTIVE}

- The goal of this project is to design and develop a medical app which must include all the treatment systems (Allopathy, Homeopathy and Ayurveda)

Revised Manuscript Received on July 22, 2019.

Priyadharshini.SP Department of Computer science and Engineering, Bharath Institute of Higher Education and Research, Chennai, Tamilnadu, India. Email: spriya07.cse@gmail.com

R.Velvizhi, Department of Computer science and Engineering, Bharath Institute of Higher Education and Research, Chennai, Tamilnadu, India. Email: velvizhisp@gmail.com

Sadagopan S, Department of Computer science and Engineering, Bharath Institute of Higher Education and Research, Chennai, Tamilnadu, India.Email: mssadagopan@gmail.com
- The details like cost of the medicine and its chemical composition of all brands and ayurvedic acupuncture related to the problems is provided and the comparison of costs is shown for selecting lowest price of branded medicine[7],[9],[11]

- The GPS tracking system is used to track nearby medical shops and hospitals and the all medical helps like health tips, pill remainder, online shop, online consultation with doctors is also available

\section{WORKING METHODOLOGY}

\section{A. Authentication:}

The first step for the app is to sign up into the user account. Firebase UI provides a customizable, open source, drop-in auth solution that handles the UI flows for signing in users[8],[10],[12]. The FirebaseUIAuth component implements best practices for authentication on mobile devices and websites, which can maximize sign-in and sign-up conversation for the app. After login it shows three option as shown in fig. 1
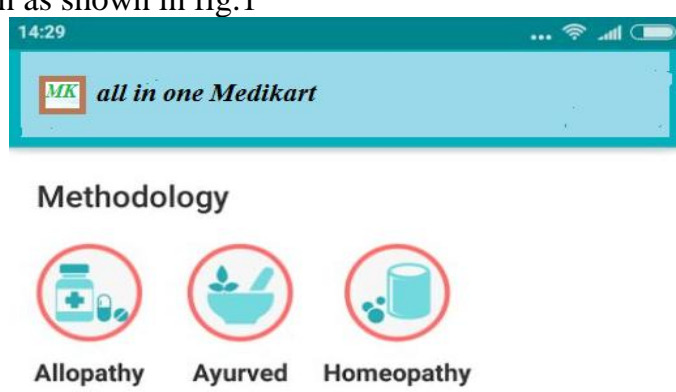

\section{B. Real time Database}

The Firebase Real time database is a cloud-hosted No SQL database that lets to store and sync data between users in real time. Real time database ships with mobile and web SDKs so our app does not need any servers[13],[15],[17].

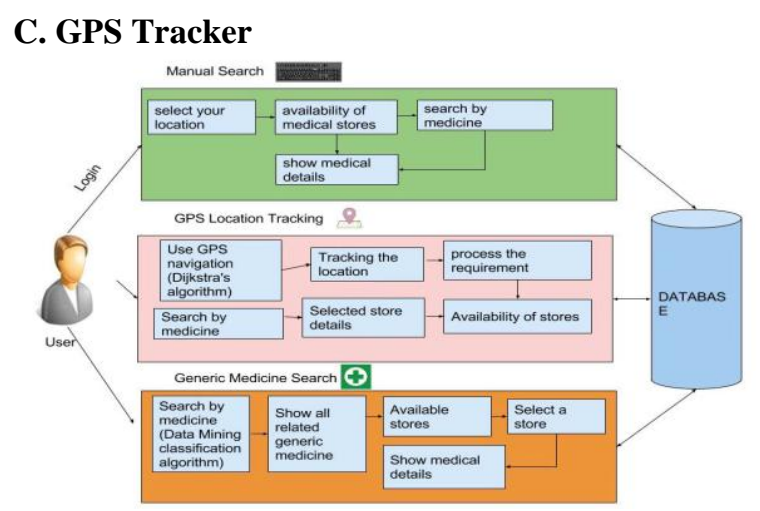

The GPS tracker is used to view the nearby medical store and hospitals. User can easily 
find out the medicine as well as medical store nearby in emergency, If the customer or user not have that much money to buy a brand medicine so he or she can easily find out the generic medicine which is low in a cost and same formula like brand medicine, If the customer is unaware about the location then the GPS system will easily track the location and as per the location the app will show the required output. The Fig. 2 shows the search of generic medicine[20],[22],[24].

\section{ALLOPATHY}

The allopathic category includes the following feature as shown in the fig. 3

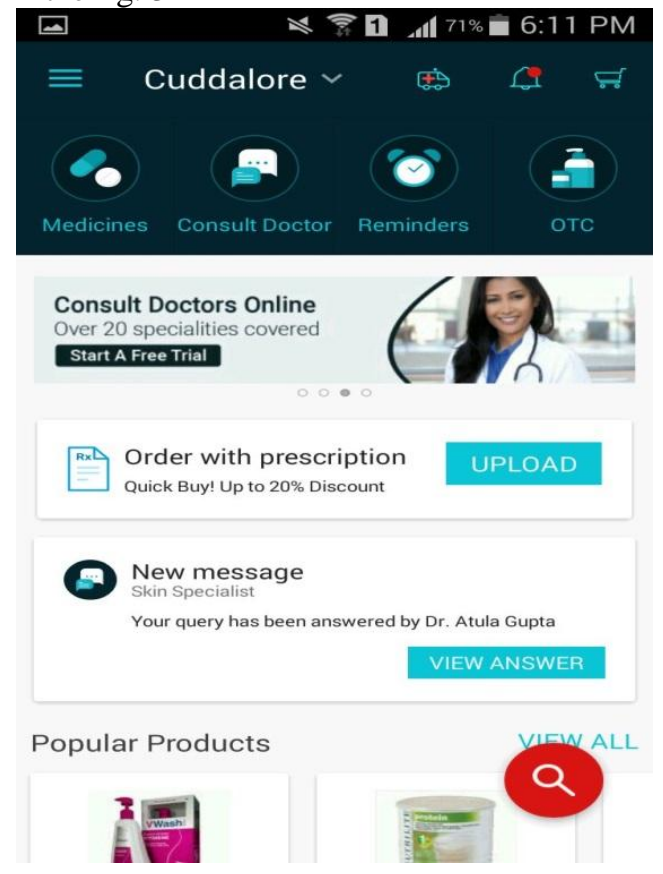

\section{E. Medicines}

The user entering into the medicine option has the search type with both the brand name and the medicine name. He/she can add it to the cart when needed[14],[16],[18]. When the user want to compare the prices of various brands of same chemical composition select compare or if he/she want to know the lowest price use filters or select generic medicine. The orders can be provided by uploading our prescription also. The comparison and search is shown

Emergency: Emergency column include call ambulance and the first aid options.

Consult Doctors: This option is used for online consultation with the doctors to our problems and symptoms and we can clarify our doubts.

Remainders: It is the pill remainder we can set for our daily consumption of tablet or periodic health checkups.

OTC: OTC provides the order list in tour cart and the details of your medical status[19],[21],[23].

ARTICLE: This section consists of the medical articles that provide updates in the technology developed in the medical field.

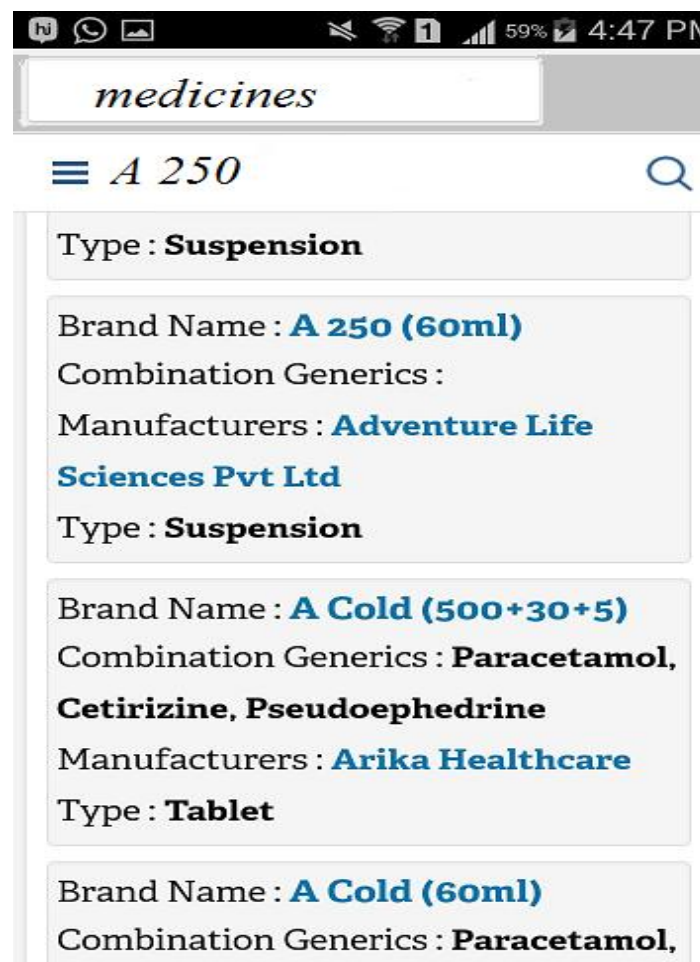

\section{CONCLUSION}

Thus the user entering into the medicine option has the search type with both the brand name and the medicine name. He/she can add it to the cart when needed. When the user want to compare the prices of various brands of same chemical composition select compare or if he/she want to know the lowest price use filters or select generic medicine.

\section{REFERENCES}

1. Gowri Sankaran, B., Karthik, B. \& Vijayaragavan, S.P. 2019, "Weight ward change region plummeting change for square based image huffman coding", International Journal of Innovative Technology and Exploring Engineering, vol. 8, no. 10, pp. 4313-4316.

2. Gowri Sankaran, B., Karthik, B. \& Vijayaragavan, S.P. 2019, "Image compression utilizing wavelet transform", International Journal of Innovative Technology and Exploring Engineering, vol. 8, no. 10, pp. 4305-4308.

3. Kandavel, N. \& Kumaravel, A. 2019, "Offloading computation for efficient energy in mobile cloud computing", International Journal of Innovative Technology and Exploring Engineering, vol. 8, no. 10, pp. 4317-4320.

4. Vinoth, V.V. \& Kanniga, E. 2019, "Reversible data hiding in encrypting images-an system", International Journal of Engineering and Advanced Technology, vol. 8, no. 6, pp. 3051-3053.

5. Selvapriya, B. \& Raghu, B. 2019, "Pseudocoloring of medical images: A research", International Journal of Engineering and Advanced Technology, vol. 8, no. 6, pp. 3712-3716.

6. Senthil Kumar, K. \& Muthukumaravel, A. 2019, "Bi-objective constraint and hybrid optimizer for the test case prioritization", International Journal of Engineering and Advanced Technology, vol. 8, no. 6, pp. 3436-3448.

7. Kavitha, G., Priya, N., Anuradha, C. \& Pothumani, S. 2019 , "Read-write, peer-to-peer algorithms for the location-identity split", International Journal of Innovative Technology and Exploring Engineering, vol. 8, no. 9 Special Issue 3, pp. 445-447.

8. Kaliyamurthie, K.P., Michael, G., Anuratha, C. \& Sundaraj, B. 2019, "Certain improvements in alzheimer disease classification using novel fuzzy c means clustering for image segmentation", International Journal of Innovative Technology and Exploring Engineering, vol. 8, no. 9 Special Issue 3, pp. 599-604. 
9. Kaliyamurthie, K.P., Sundarraj, B., Geo, A.V.A. \& Michael, G. 2019 "RIB: Analysis of I/O automata", International Journal of Innovative Technology and Exploring Engineering, vol. 8, no. 9 Special Issue 3, pp. 1019-1022.

10. Velvizhi, R., Rajabhushanam, C. \& Vidhya, S.R.S. 2019, "Opinion mining for travel route recommendation using Social Media Networks (Twitter)", International Journal of Innovative Technology and Exploring Engineering, vol. 8, no. 9 Special Issue 3, pp. 508-512.

11. Kavitha, R., Sangeetha, S. \& Varghese, A.G. 2019, "Human activity patterns in big data for healthcare applications", International Journal of Innovative Technology and Exploring Engineering, vol. 8, no. 9 Special Issue 3, pp. 1101-1103.

12. Pothumani, S., Anandam, A.K., Sharma, N. \& Franklin, S. 2019, "Extended VEOT framework - Implemented in a smart boutique", International Journal of Innovative Technology and Exploring Engineering, vol. 8, no. 9 Special Issue 3, pp. 762-767.

13. Kaliyamurthie, K.P., Michael, G., Krishnan, R.M.V. \& Sundarraj, B. 2019, "Pseudorandom techniques for the internet", International Journal of Innovative Technology and Exploring Engineering, vol. 8, no. 9 Special Issue 3, pp. 915-918.

14. Aravindasamy, R., Jeffrin Rajan, M., Rama, A. \& Kavitha, P. 2019 "Deep learning provisions in the matlab: Focus on CNN facility", International Journal of Innovative Technology and Exploring Engineering, vol. 8, no. 9 Special Issue 3, pp. 990-994.

15. Theivasigamani, S., Linda, M. \& Amudha, S. 2019, "Object sensing and its identification \& motion sensing", International Journal of Innovative Technology and Exploring Engineering, vol. 8, no. 9 Special Issue 3, pp. 545-549.

16. Mary Linda, I., Vimala, D. \& Shanmuga Priya, K. 2019, "A methodology for the emulation of IPv4", International Journal of Innovative Technology and Exploring Engineering, vol. 8, no. 9 Special Issue 3, pp. 848-852.

17. Velvizhi, R., Priya, D.J., Vimala, D. \& Linda, I.M. 2019, "Increased routing algorithm for mobile adhoc networks", International Journal of Innovative Technology and Exploring Engineering, vol. 8, no. 9 Special Issue 3, pp. 1606-1608

18. Sangeetha, S., Anuradha, C. \& Priya, N. 2019, "DNS in real world", International Journal of Innovative Technology and Exploring Engineering, vol. 8, no. 9 Special Issue 3, pp. 937-940.

19. Geetha, C., Vimala, D. \& Priya, K.S. 2019, "Constructing multi-processors and spreadsheets with SKIVE", International Journal of Innovative Technology and Exploring Engineering, vol. 8, no. 9 Special Issue 3, pp. 516-519.

20. Yugendhar, K., Sugumar, V. \& Kavitha, P. 2019, "A novel method of univac using fuzzy logic", International Journal of Innovative Technology and Exploring Engineering, vol. 8, no. 9 Special Issue 3, pp. 435-437.

21. Kaliyamurthie, K.P., Michael, G., Elankavi, R. \& Jijo, S.A. 2019, "Implementing aggregate-key for sharing data in cloud environment using cryptographic encryption", International Journal of Innovative Technology and Exploring Engineering, vol. 8, no. 9 Special Issue 3, pp. 957-959.

22. Jeffrin Rajan, M., Aravindasamy, R., Kavitha, P. \& Rama, A. 2019, "A novel method of object orientation variation in $\mathrm{C}++$ and java", International Journal of Innovative Technology and Exploring Engineering, vol. 8, no. 9 Special Issue 3, pp. 708-710.

23. Nayak, R., Dinesh, S. \& Thirunavukkarasu, S. 2019, "A novel method improvement of rapid miner for the data mining applications", International Journal of Innovative Technology and Exploring Engineering, vol. 8, no. 9 Special Issue 3, pp. 457-460.

24. Sivaraman, K., Krishnan, R.M.V., Sundarraj, B. \& Sri Gowthem, S. 2019, "Network failure detection and diagnosis by analyzing syslog and SNS data: Applying big data analysis to network operations", International Journal of Innovative Technology and Exploring Engineering, vol. 8, no. 9 Special Issue 3, pp. 883-887.

25. Vimala, D., Linda, I.M. \& Priya, K.S. 2019, "Decoupling online algorithms from erasure coding in DNS", International Journal of Innovative Technology and Exploring Engineering, vol. 8, no. 9 Special Issue 3, pp. 950-953.

26. Rama, A., Kumaravel, A. \& Nalini, C. 2019, "Preprocessing medical images for classification using deep learning techniques", International Journal of Innovative Technology and Exploring Engineering, vol. 8, no. 9 Special Issue 3, pp. 711-716.

27. Sangeetha, S., Srividhya, S.R., Anita Davamani, K. \& Amudha, S. 2019, "A procedure for avoid overrun error in universal synchronous asynchronous receiver transmitter (usart) by utilizing dummy join and interrupt latency method", International Journal of Innovative
Technology and Exploring Engineering, vol. 8, no. 9 Special Issue 3, pp. 657-660

28. Aravindasamy, R., Jeyapriya, D., Sundarajan, B. \& Sangeetha, S 2019, "Data duplication in cloud for optimal performance and security", International Journal of Innovative Technology and Exploring Engineering, vol. 8, no. 9 Special Issue 3, pp. 1156-1158.

29. Aravindasamy, R., Jeffrin Rajan, M., Sugumar, V. \& Kavitha, P. 2019, "A novel method on developing superblocks and the transistor using apodryal", International Journal of Innovative Technology and Exploring Engineering, vol. 8, no. 9 Special Issue 3, pp. 982-985.

30. Sasikumar, C.S. \& Kumaravel, A. 2019, "E-learning attributes selection through rough set theory and data mining", International Journal of Innovative Technology and Exploring Engineering, vol. 8, no. 10 , pp. $3920-3924$

\section{AUTHORS PROFILE}

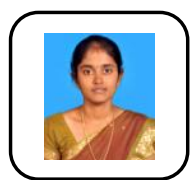

Priyadharshini.SP Assistant Professor, Department of Computer science and Engineering, Bharath Institute of Higher Education and Research, Chennai, India

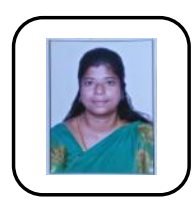

R.Velvizhi Assistant Professor, Department of Computer science and Engineering, Bharath Institute of Higher Education and Research, Chennai, India

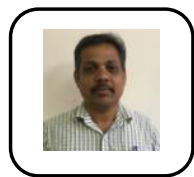

Sadagopan S Assistant Professor, Department of Computer science and Engineering, Bharath Institute of Higher Education and Research, Chennai, India 